\title{
Biomass and height of Ascophyllum nodosum after two decades of continuous commercial harvesting in eastern Canada
}

\author{
Jean-Sébastien Lauzon-Guay ${ }^{1} \cdot$ Raúl A. Ugarte $^{1} \cdot$ Bryan L. Morse $^{1} \cdot$ Collette A. Robertson $^{1}$ \\ Received: 28 September 2020 / Revised and accepted: 15 February 2021 / Published online: 8 March 2021 \\ (C) The Author(s) 2021
}

\begin{abstract}
With the increasing demand for seaweed resources worldwide, management must ensure that the harvest of wild seaweed stocks is sustainable. We evaluate the impact of over 25 years of commercial harvesting of Ascophyllum nodosum in eastern Canada by comparing the biomass and height of the seaweed in the late 1990s to the late 2010s over a broad spatial scale spanning the provinces of Nova Scotia and New Brunswick. There has been no significant decrease in the biomass of A. nodosum in either province, and biomass has increased in some regions of New Brunswick during that period. The average height of $A$. nodosum has decreased by $7.8 \mathrm{~cm}$ in Nova Scotia while it increased by $13.8 \mathrm{~cm}$ in New Brunswick. Biomass of $A$. nodosum in unharvested sectors was $7 \%$ higher than that in harvested sectors while height of A. nodosum in unharvested sectors in New Brunswick is similar to the values observed in harvested sectors. Over the same period, water temperature has increased in both provinces and, in recent years, has at times exceeded the optimal growing temperature for A. nodosum within bays in Nova Scotia. We conclude that the current management and harvest of $A$. nodosum in eastern Canada are sustainable and maintain the biomass and height of A. nodosum beds but that control sites are necessary to offer adequate comparisons as environmental conditions are changing.
\end{abstract}

Keywords Seaweed $\cdot$ Ascophyllum nodosum $\cdot$ Harvest $\cdot$ Management $\cdot$ Nova Scotia $\cdot$ New Brunswick $\cdot$ Rockweed

\section{Introduction}

Demand for seaweed and seaweed products is rapidly increasing worldwide. While cultivation accounts for most of the global production (96\%; FAO 2018), harvesting of wild stocks continues to play a vital role in the sustainable livelihood of many coastal communities (Rebours et al. 2014) despite the fact that only a fraction of the 10,000 algal species known are being commercially harvested (Mac Monagail et al. 2017). Given the ecological importance of seaweed in primary production, carbon cycling, detrital production, and

Jean-Sébastien Lauzon-Guay

jlauzonguay@acadian.ca

Raúl A. Ugarte

rugarte@acadian.ca

Bryan L. Morse

bmorse@acadian.ca

Collette A. Robertson

crobertson@acadian.ca

1 Acadian Seaplants Limited, 30 Brown Avenue, Dartmouth, Nova Scotia B3B 1X8, Canada carbon sequestration as well as habitat and food for a whole community of organisms, a proper management framework is essential to ensure their sustainable harvest (Lotze et al. 2019). Without considered management, some seaweed resources could become overexploited (Vásquez 2008), and their harvest can have an impact on multiple trophic levels within a food web (Lorentsen et al. 2010).

Ascophyllum nodosum (Linnaeus) Le Jolis is the main seaweed species harvested in Canada and often dominates the intertidal zone along the northern Atlantic coast where it forms extensive beds. Ascophyllum nodosum is a modular species with several shoots originating from a single holdfast (Lazo and Chapman 1998). Holdfasts can fragment and coalesce over time, making it difficult to differentiate individuals without destructive sampling (Åberg 1989). All shoots originating from an apparent single holdfast can be considered a clump. There is a long history of harvest of A. nodosum in coastal Europe, where it was initially used as a soil amendment before being used for alginate production (Guiry and Morrison 2013). In recent years, A. nodosum has been mainly used as plant biostimulants (Shukla et al. 2019) and as feed supplements (Evans and Critchley 2014). In North America, A. nodosum has been harvested for soil amendment since at least the early 1900s in Maine (Anonymous 1907) with a 
commercial harvest starting in Canada in the late 1950s along the coastal areas of southwestern Nova Scotia (NS).

Initially, the harvest of $A$. nodosum in NS was an open fishery with no limit on the number of harvesters, their area of operation, or the level of exploitation. In 1959, the Nova Scotian government issued a few exclusive-purchasing licenses in southwestern NS (Ugarte and Sharp 2001), followed by the introduction of area-based management to some regions in the late 1970s. Since 1995, most of the harvest takes place within leases divided into sectors. Leases are awarded to individual companies who must provide third-party audited biomass assessments and harvest plans prior to any harvesting activities taking place in a lease. All data used to perform the biomass assessment must be evaluated by an independent third-party auditor approved by the Province. Two major regulatory requirements for the harvest are that $A$. nodosum attached to holdfast may not exceed $15 \%$ by weight of the total harvested material, and there is a minimum cutting height of $12.7 \mathrm{~cm}$ above the holdfast. The proportion of the biomass that can be harvested annually is established on a lease by lease basis by the provincial government and does not exceed $25 \%$. Harvest reports including biomass harvested per sector must be submitted to the government at the end of the year. Both manual and mechanical harvesting techniques were used concurrently in NS by different companies from the early 1970s until 1994 (Ugarte and Sharp 2001). Since 1995, there have been no mechanical harvesters active in eastern Canada (Ugarte and Sharp 2001), apart from experimental trials conducted under the supervision of the Nova Scotian government (Wendy Vissers, Nova Scotia Department of Fisheries and Aquaculture, pers. comm.). At present, Acadian Seaplants Limited (ASL) harvests the majority of A. nodosum in NS.

In New Brunswick (NB), the initial management plan was developed before any harvest had taken place. Following a precautionary approach, the sustainability of the resource and protection of the environment were explicitly stated as goals of the initial agreement between the provincial and federal governments (Anonymous 1994). The development of the A. nodosum harvest in NB resulted in new and beneficial approaches to coastal resource management by integrating habitat, stakeholder, and social-economic issues (Ugarte and Sharp 2001). The potential impact of the harvest on the entire ecosystem was evaluated, and regulations developed to prevent the harvest from creating significant long-term changes in habitat structure (Ugarte and Sharp 2001). Area-based management was instated from the onset of the pilot harvest in 1995. The coast was divided into sectors, and ASL was awarded the exclusive harvesting license for NB. Study areas, special rockweed management areas for the protection of waterfowl, and permanently closed areas, were established. Similar regulations to those instated in NS were applied, and only manual harvest from small boats using a specially designed cutting rake was permitted (Fig. 1a). Holdfast may not exceed $10 \%$ by weight of the total harvested material and the annual harvest rate was limited to $17 \%$ of the standing stock. This level was chosen as being conservative and based on the observation that full recovery of the biomass was observed within 3 years following removal of $50 \%$ of the biomass (Sharp and Tremblay 1989).

Since 1995, ASL has carried out A. nodosum surveys in NS and NB to monitor the condition of the resource and set harvest quotas. The objective of this study was to evaluate the condition of A. nodosum 25 years after the implementation of the current harvesting regulations. We present biomass and height, two of the primary morphological descriptors of A. nodosum, during two periods. The first period (between 1996 and 1998) represents the onset of the NB harvest (1995) and the transition between harvesting periods in NS. This period witnessed changes in the number of companies active in the region, increased regulations, and an increase in A. nodosum landings. The second period (2016-2020) represents the current conditions after two decades of continuous harvest. Both areas analyzed have been harvested exclusively by ASL since 1995 and regulations have been strictly followed. Government conservation officers enforce the harvesting regulations, and ASL contracts an independent third-party dockside monitoring company to monitor landings.

\section{Methods}

\section{Study areas}

Sampling for this study was carried out in the vicinity of Lobster Bay in Southwest NS, Canada, and the western part of the Bay of Fundy including Grand Manan Island in NB, Canada (Fig. 2). In NS, Lobster Bay has a long history of commercial harvest of $A$. nodosum dating back to the $1960 \mathrm{~s}$ (Ugarte and Sharp 2012). Within the leases harvested by ASL in Lobster Bay, average annual landings were 5,978 wet $\mathrm{t}$ between 1993 and 1997 and, as more sectors were harvested, had more than doubled to 13,250 wet t between 2014 and 2018. The area of the South Shore included in this study was sporadically harvested in the early 1990s (Glyn Sharp pers. comm.) and then again starting in 1998 until now by ASL. The exact harvested quantities are confidential but represent $20-25 \%$ of the available $A$. nodosum biomass. There is currently one other company also harvesting in other leases in Lobster Bay and the South Shore, and their landings are not included in the quantities above. Ascophyllum nodosum is also being harvested along most of the Nova Scotian shoreline between St. Mary's Bay and Canso.

The NB harvest started in 1995 with only 703 wet t harvested during the first year. The harvest increased to 2,800 wet $\mathrm{t}$ the following year before increasing to over 12,000 wet $\mathrm{t}$ by 2009 (Ugarte and Sharp 2012). Ascophyllum nodosum is 

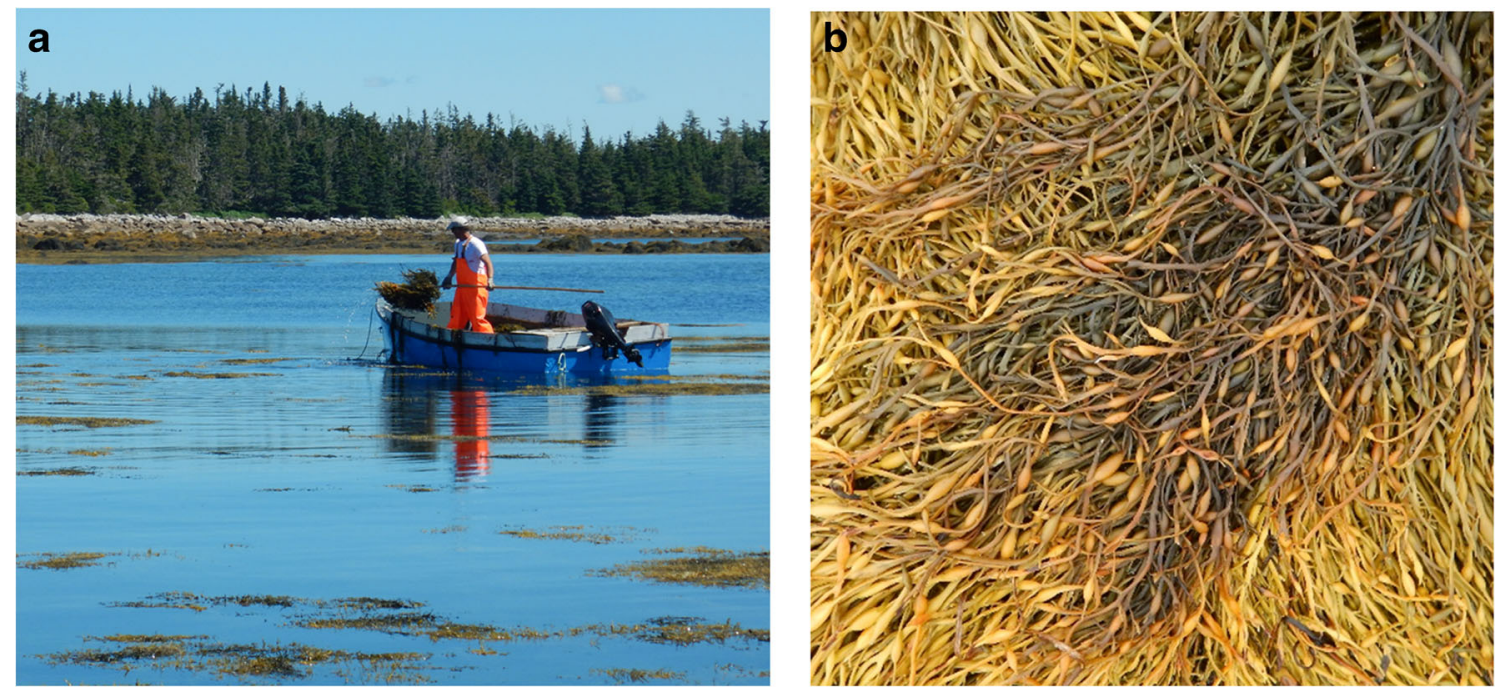

Fig. 1 a Harvesting of Ascophyllum nodosum in southwest Nova Scotia, Canada, using a cutter rake. b Heat-damaged (brown discolouration) Ascophyllum nodosum from an unharvesed bed in Nova Scotia in August 2016

harvested in NB from the St. Croix River at the border with the USA to Saint John, NB, including the Grand Manan archipelago. Within the area included in the present study, the average yearly landing was 3,096 wet $t$ during the first period of data collection. Conversely, during the second period between 2016 and 2020, the average yearly landing had more than tripled to reach 11,142 wet $t$.

The study areas are characterized by semidiurnal tides with an average amplitude of $7 \mathrm{~m}$ and $3 \mathrm{~m}$ in NB and NS, respectively. These large tidal ranges can lead to wide intertidal zones (several $100 \mathrm{~s} \mathrm{~m}$ ) as well as strong tidal currents. In both provinces, the substratum within our study areas is composed of bedrock and boulders along the exposed coastline and a mix of cobbles mixed with mud and sand along the most sheltered areas. The outer islands of Lobster Bay and the South Shore region, as well as Grand Manan, are directly exposed to the North Atlantic Ocean swell. Generally, the rest of the NB regions and the inner areas of Lobster Bay are protected from waves and swell from the open ocean.

\section{Sampling procedure}

Data were collected during two distinct periods: (1) the onset of the current harvesting rules in the mid-1990s (1996-1998, hereafter the 1990s) and (2) in recent years (2016-2020, hereafter the 2010s). In 1996, ASL started conducting extensive biomass surveys of A. nodosum in NS and NB. The purpose of the surveys was to estimate the biomass of $A$. nodosum so that sustainable harvesting quotas could be established for each sector. Sampling was done during a 4-h window around low tide. Transect locations were selected haphazardly within the main beds, attempting to obtain a representative sampling of A. nodosum within each sector. Between 1 and 6 transects were deployed within each sector depending on the size of the sector. In NS, sampling took place between October and May between 1996 and 1998. Seasonal reproduction of A. nodosum occurs in late spring, a time when reproductive receptacles rapidly increase in weight and can account for over $50 \%$ of the weight of a clump (Vadas et al. 2004). Therefore, all samples collected in April and May were excluded from the analysis. In NB, sampling took place outside of the reproductive season (April and May) and therefore all samples were kept for analysis.

In the 1990s, a transect line was deployed from the low water mark to the top of the A. nodosum zone, perpendicular to the shore. Between five and fifteen $100 \times 50 \mathrm{~cm}$ quadrats $\left(0.5 \mathrm{~m}^{2}\right)$ were randomly positioned along the transect. In each quadrat, three clumps (a clump consists of all shoots originating from a common holdfast) were haphazardly selected, and their height measured to the nearest $1 \mathrm{~cm}$ with a meter ruler. Because the sampling of clumps is haphazard within each quadrat, very small clumps hidden under the canopy are less likely to be measured. Our estimates of height therefore represent the average canopy height rather than the average height of all clumps within a quadrat. We have detected no sampling bias between individuals making the measurements. All A. nodosum shoots were cut $15 \mathrm{~cm}$ away from the holdfast and weighed in a mesh dive bag using a digital hook scale (brand and accuracy information unavailable). The mass of A. nodosum above $15 \mathrm{~cm}$ from the holdfast per unit area is defined as biomass in the present study. Over time, ASL has modified its sampling methodology to obtain a more accurate estimate of the biomass within the central area of the beds (mid-intertidal) where most of the harvest takes place (R. Ugarte, pers. obs). In the 2010s, a 30-m transect line was deployed in the center of the $A$. nodosum zone, parallel to shore with ten $50 \times 50 \mathrm{~cm}\left(0.25 \mathrm{~m}^{2}\right)$ quadrats randomly positioned along the length of the transect. Ascophyllum nodosum 
Fig. 2 Map of eastern Canada with insets showing the regions (New Brunswick: Letang, Passamaquoddy Bay (PB), Grand Manan (GM), Deer Is (DI); Nova Scotia: Lobster Bay and South Shore), sectors, and sampling sites within unharvested sectors (NB only) in New Brunswick and Nova Scotia, Canada. The location of the Point Lepreau (PL) and Yarmouth Airport (YA) weather stations are indicated on the insets

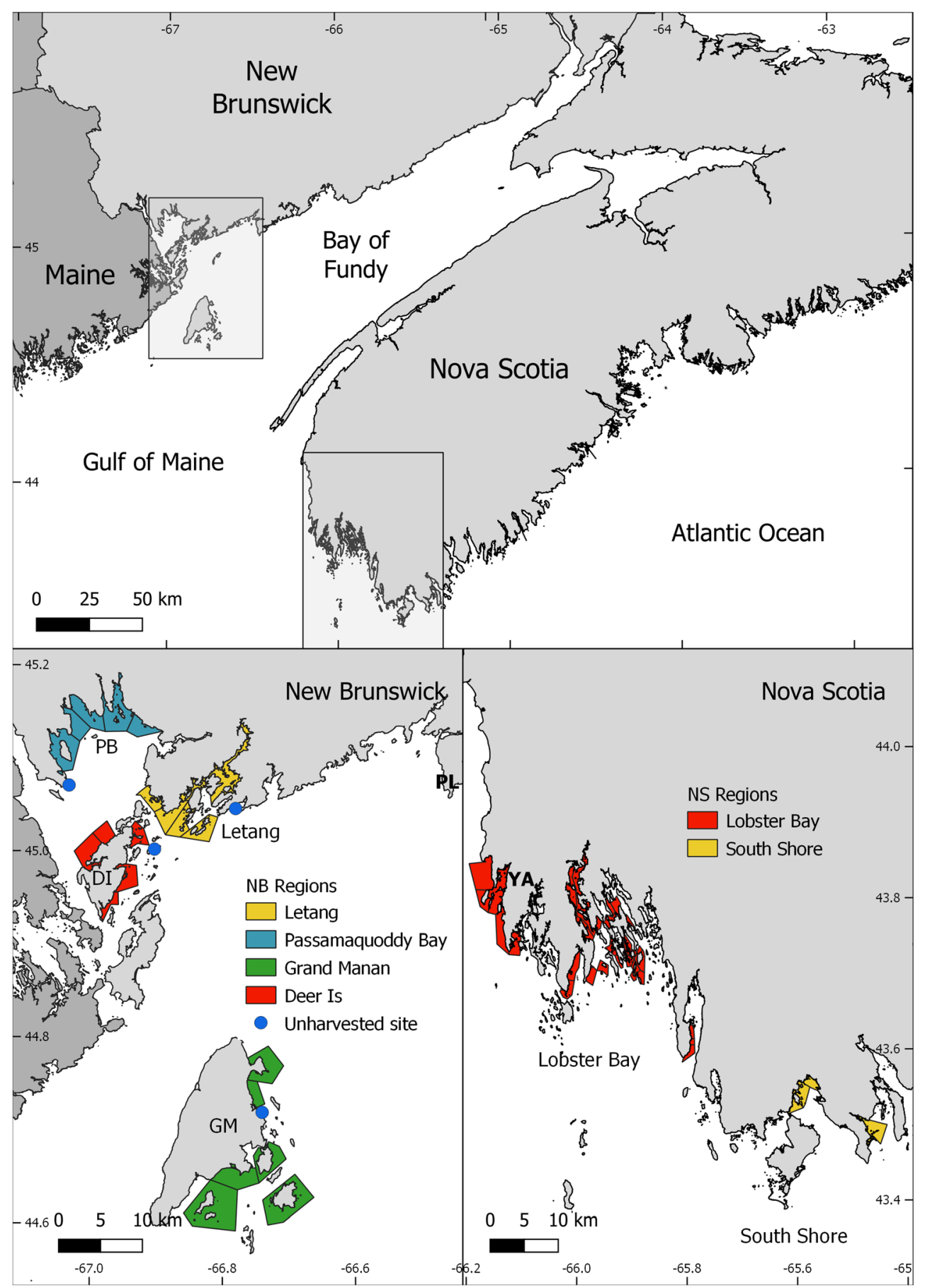

height and biomass were still measured in a similar manner as in the 1990s, with 3 clumps measured for height per quadrat and all A. nodosum biomass $15 \mathrm{~cm}$ above the holdfast removed and weighed. In recent years, data have been collected between the end of the reproductive season after the shedding of receptacles in early June, and early Fall, so that only vegetative biomass is included.

In order to compare data from the perpendicular transects from the 1990s to the parallel transects from the 2010s, we subsampled the 1990s data and only included the middle third of the quadrats, which eliminated the quadrats from the upper and lower intertidal zone and only kept those originating from the mid-intertidal zone. All transects and all quadrats were positioned in the mid-intertidal zone in the $2010 \mathrm{~s}$. Ascophyllum nodosum is shorter and less abundant higher up on the shore, and including quadrats from that location would have decreased the average height and biomass at each site, thus reducing the likelihood of detecting a significant decrease of either parameter following several years of harvesting activities. During the winter of 2015, NS experienced 
unusually high ice cover, which resulted in significant ice damage to A. nodosum and a considerable reduction in biomass in several sectors (ASL, unpublished data). Therefore, biomass and height data before 2017 were not included in the analyses for NS. No similar ice damage was observed in NB at that time, and data from all years were kept. It is possible that the impact from ice damage was still influencing the height and biomass of $A$. nodosum after 2016, but because we had no previous record of ice damage prior to our sampling in 1995 , we decided to include those subsequent years in the analysis. If anything, our estimates are underestimating the current condition of $A$. nodosum in the absence of ice damage.

Our study has one important shortcoming; it does not have control sites sampled during both periods to assess the natural changes that may have occurred in the absence of harvesting activities. Such sites were not sampled in the 1990s. Therefore, it was not possible to determine whether the pattern observed was due to harvest management or whether the environmental conditions changed. Nevertheless, by having four unharvested sectors sampled in NB in August 2020 (Fig. 2), we attempted to answer this question. In each of those sectors, samples were measured along three transects as per the sampling methodology described above for the 2010s. Those sectors were not sampled in the 1990s and could not be used as control sites in the analysis but can be used as a reference point. No unharvested sectors in the vicinity existed in NS.

\section{Water and air temperature}

Sea surface water temperature (SST) data were extracted from the NOAA 0.25-degree Daily Optimum Interpolation Sea Surface Temperature, V2.1 (https://coastwatch.pfeg.noaa. gov/erddap/index.html) and averaged over the extent of the study sites in NS and NB.

Historical daily air temperature data were obtained from the Environment and Natural Resources Canada website (https://climate.weather.gc.ca/historical_data/search_ historic_data_e.html). The Point Lepreau $\left(66.45^{\circ} \mathrm{W}, 45.07^{\circ}\right.$ $\mathrm{N})$ and Yarmouth Airport $\left(66.09^{\circ} \mathrm{W}, 43.83^{\circ} \mathrm{N}\right)$ weather stations were the closest to our study areas in NB and NS respectively (Fig. 2).

\section{Data analysis}

To ensure that data collected during both periods (the 1990s and 2010s) originated from the same general areas, we used sectors as our main unit of replication rather than individual transects from sampling sites. We only used data from sectors for which we had at least two transects from each sampling period. Some sampling sites may have been visited more than once within each period (sampling site coordinates were not recorded in the 1990s), and because the number of transects sampled varied between sectors and periods, we calculated the average height and biomass of $A$. nodosum within each sector for each period. This ensured that each replicate is independent, and it provides a more balanced design between periods. Our main objective was not to analyze the fine-scale changes in biomass within individual sectors but to gain insights into the potential largescale changes after 20 years of continuous commercial harvesting. To account for regional differences in environmental condition and harvesting history, we divided each province into regions. NS was divided into two regions, Lobster Bay (extending from Yarmouth to Pubnico as per Sharp 1991; Fig. 2), and the South Shore (extending from Cape Sable Island to Shelburne; Fig. 2). Biomass and height data collected from Lobster Bay are within NS Rockweed Leases 6003 and 6011, while data from the South Shore were collected from Lease 6006 (https://novascotia.ca/fish/aquaculture/sitemapping-tool/). NB was divided into four regions (Letang, Passamaquoddy Bay, Deer Island and Grand Manan; Fig. 2).

Changes in height and biomass were analyzed using ANOVAs with type 3 sums of squares with Period as a fixed factor with two levels (1990s and 2010s), and Region as a fixed factor (2 levels in NS and 4 levels in NB). Data from both provinces were analyzed separately. Provinces differ in terms of sampling years, harvest regulations, and harvest history, making any comparisons between provinces confounded by many factors. Homoscedasticity was assessed using Levene's test and normality was assessed visually from a Q-Q plot prior to analysis and data were log-transformed where required to meet the assumptions. When a significant Region effect was detected, multiple comparisons were carried out using Tukey's HSD test. Because the statistical power to detect interactions is often low, we set the alpha value for interactions at 0.20 (Selvin 1996) and proceeded with four pre-planned independent contrasts to compare each region separately over time. Size-frequency distributions were described by calculating the 50th (median) as well as the 5th and 95th quantiles. Without replicate unharvested sectors within each region and some unharvested sectors laying in the periphery of the regions, it is difficult to draw meaningful conclusions because the seaweed within those sectors may not be representative of the whole region. Rather than making statistical comparisons, we assessed whether the average values measured in the unharvested sectors compare with the values measured in harvested sectors. To compare the averaged annual SST and air temperature profiles between both periods, we averaged the weekly temperature during the 1990s and during the 2010s. Temporal trends in SST and air temperature were assessed using linear regressions on the monthly average temperature for each year. Because the upper thermal tolerance for A. nodosum is in the range of 27 to $29^{\circ} \mathrm{C}$ (Keser et al. 2005), we calculated the average number of days above $26{ }^{\circ} \mathrm{C}$ within a year for each decade. All analyses were done in R v4.0.2 (R Core Team 2020). 
Unless mentioned otherwise, data are mean \pm 1 standard deviation.

\section{Results}

\section{Lobster Bay, Nova Scotia}

A total of 479 transects were sampled between 1996 and 1998 in Lobster Bay, NS. Of those, 231 were outside of the reproductive season (April and May) and were kept for analysis (Online Resource 1). Of all sectors sampled, 39 (35 in Lobster Bay and 4 on the South Shore, where only three sectors had height data on the South Shore) were sampled at least twice during each period and were kept for analysis. During the 2010s, 125 transects were sampled within those same sectors and included in the analysis. For biomass, there was no statistically significant interaction between Period and Region in NS $\left(F_{1,74}=0.104, P=0.747\right)$. We observed no significant change in $A$. nodosum biomass between Periods $\left(F_{1,74}=0.170, P=0.681\right)$ or Regions $\left(F_{1,74}=0.073, P=0.788\right)$ with an overall average $A$. nodosum biomass of $9.93 \pm$ $3.99 \mathrm{~kg} \mathrm{~m}^{-2}$ and $9.54 \pm 2.02 \mathrm{~kg} \mathrm{~m}^{-2}$ for the $1990 \mathrm{~s}$ and 2010s samples, respectively (Fig. 3a). As was the case for biomass, there was no significant interaction between Period and Region for height in NS $\left(F_{1,72}=0.007, P=0.933\right)$ and no significant difference between regions $\left(F_{1,72}=0.002\right.$, $P=0.990)$. We observed a significant $7.8-\mathrm{cm}$ decrease in mean clump height between the 1990s and the 2010s $\left(F_{1,72}=7.045\right.$, $P=0.010$ ) with the average clump height decreasing from 93.2 $\pm 12.6 \mathrm{~cm}$ in $1990 \mathrm{~s}$ to $85.5 \pm 11.8 \mathrm{~cm}$ in $2010 \mathrm{~s}$ (Fig. 3b). The combined height frequency distribution shows unimodal distributions for both periods (Fig. 4). The right tails of the distributions have a similar upper limit (95th quantile: 132.7 and $143 \mathrm{~cm}$ for 1990s and 2010s, respectively), suggesting that the height of the clumps forming the upper canopy did not decrease over time but while short clumps $(<60 \mathrm{~cm})$ represented only $5 \%$ of clumps in the 1990 s, they accounted for $20 \%$ of clumps in the 2010s (Fig. 4). Similarly, the 5th quantile was $54.4 \mathrm{~cm}$ in the $1990 \mathrm{~s}$ vs $37.0 \mathrm{~cm}$ in the $2010 \mathrm{~s}$. Without data on settlement and recruitment along with more extensive sampling of all clumps within quadrats, it is difficult to infer a cause to this observation.

\section{Bay of Fundy, New Brunswick}

From the 143 transects sampled in NB in the 1990s, 121 transects were used for comparisons, having at least two transects from each sector from both periods. Comparatively, 119 transects from the 2010s were included in the analysis (Online Resource 1). This provided sufficient data to include six sectors for Passamaquoddy Bay and five sectors each for Grand Manan, Letang and Deer Island.
There was no significant interaction $\left(F_{3,34}=1.644\right.$, $P=0.197)$ or main effect of Region $\left(F_{3,34}=1.129, P=0.351\right)$ or Period $\left(F_{1,34}=3.188, P=0.083\right)$ on the biomass of A. nodosum in NB (Fig. 5a). Although it was marginally not statistically significant, the average biomass of $A$. nodosum, based on the 21 sectors included in this analysis, increased from $9.43 \pm 2.62 \mathrm{~kg} \mathrm{~m}^{-2}$ in the $1990 \mathrm{~s}$ to $10.82 \pm 2.35 \mathrm{~kg}$ $\mathrm{m}^{-2}$ in the 2010s. Despite the non-significant interaction between Period and Region and the lack of an overall Period effect, contrasts indicated a significant increase in biomass in Passamaquoddy Bay $\left(t_{1,34}=2.177, P=0.026\right)$. A similar marginally non-statistically significant increase was also observed in Letang $\left(t_{1,34}=1.786, P=0.083\right)$, while both offshore regions remained unchanged over time (Fig. 5a). The average biomass within the harvested sectors $\left(10.82 \pm 2.35 \mathrm{~kg} \mathrm{~m}^{-2}\right)$ was $7.5 \%$ lower than the average value for the unharvested sectors $\left(11.64 \pm 1.84 \mathrm{~kg} \mathrm{~m}^{-2}\right)$. This difference represents less than half the biomass removed annually during the harvest (17\% harvest rate).

Conversely, while the interaction between Period and Region was not statistically significant for clump height $\left(F_{3,34}=0.510, P=0.678\right)$, there was a significant effect of Period $\left(F_{1,34}=5.341, P=0.027\right)$ and Region $\left(F_{3,34}=2.999\right.$, $P=0.044)$. We observed an average increase across regions of $13.8 \mathrm{~cm}$ in clumps height from $81.2 \pm 16.5 \mathrm{~cm}$ in the 1990s to $95.0 \pm 13.8 \mathrm{~cm}$ in the 2010s in NB. Pre-planned contrasts indicated that Passamaquoddy Bay had taller A. nodosum than Grand Manan $\left(t_{1,34}=3.184, P=0.016\right)$, while the height of $A$. nodosum did not vary significantly between other regions (Fig. 5b). The average height of $A$. nodosum within the unharvested sectors $(96.7 \pm 10.5 \mathrm{~cm})$ was similar to the average in harvested sectors $(95.0 \pm 13.8 \mathrm{~cm})$.

We observed an overall shift in the entire height frequency distribution between the 1990s to the 2010s (Fig. 6). The median height in the $1990 \mathrm{~s}$ was $80.0 \mathrm{~cm}(35.5$ $124.0 \mathrm{~cm}, 5$ th and 95 th quantiles) and $94.0 \mathrm{~cm}(51.0-152.1$ $\mathrm{cm})$ in the $2010 \mathrm{~s}$. The frequency of clumps taller than $100 \mathrm{~cm}$ doubled over the last 20 years, and clumps taller than $130 \mathrm{~cm}$, a rarity in the 1990s in NB, are now much more prevalent (Fig. 6). Conversely, short clumps $(<60$ $\mathrm{cm})$ which accounted for $20 \%$ of clumps in the $1990 \mathrm{~s}$ accounted for $10 \%$ in the 2010 s (Fig. 6).

\section{Water and air temperature}

In both provinces, SST has increased by an average of $1.2{ }^{\circ} \mathrm{C}$ and $0.9^{\circ} \mathrm{C}$ in NB and NS, respectively, between the 1990s and the 2010s. In NB, SST increased for all periods except for late July and early August where SST remained relatively constant (Fig. 7a). In NS, SST decreased between the two periods in July and August but increased during the rest of the year (Fig. $7 \mathrm{a})$. Sea surface temperature is generally warmer in NB than NS in the spring and has increased more rapidly in NB than 

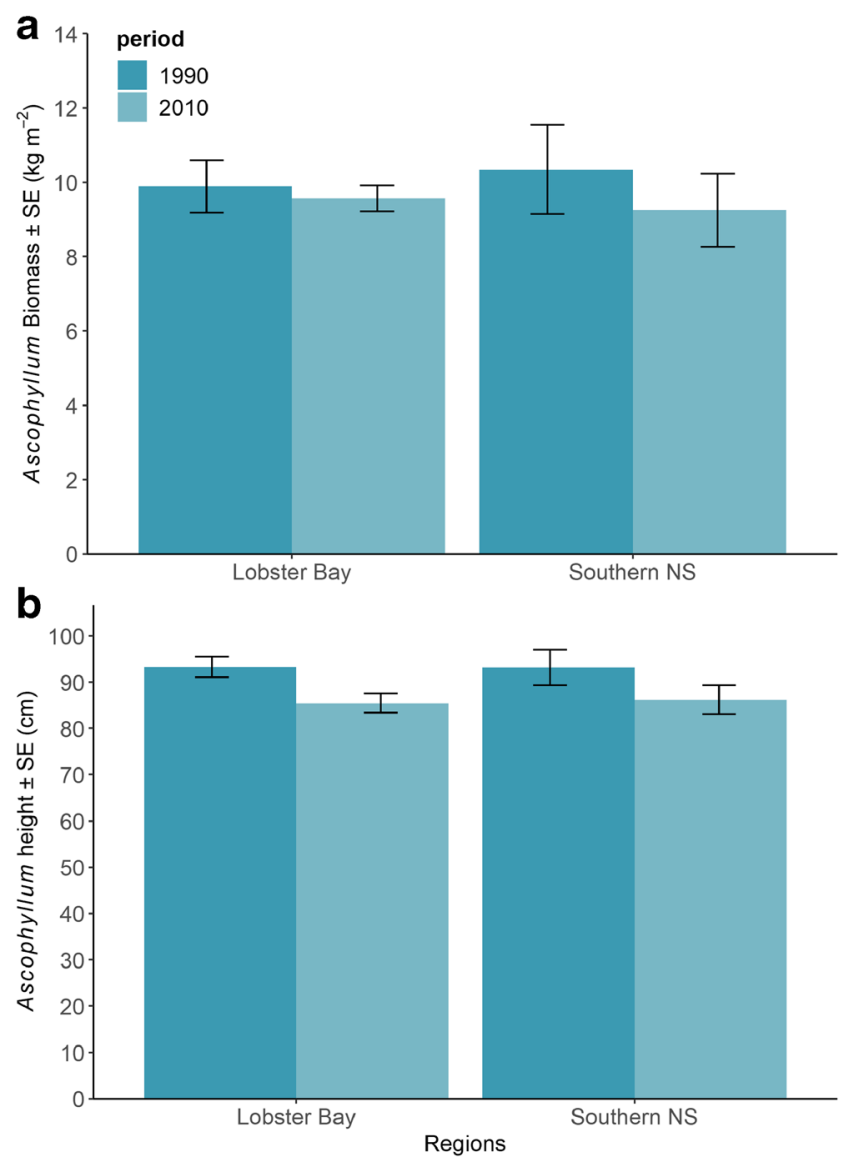

Fig. 3 Average biomass $\left(\mathbf{a}, \mathrm{kg} \mathrm{m}^{-2}\right)$ and height $(\mathbf{b}, \mathrm{cm})$ of Ascophyllum nodosum from Lobster Bay, Nova Scotia for two sampling periods (1990s and 2010s)

NS in May (Fig. 7b). The opposite occurred during the fall when NS has warmer water temperature than NB. During October, SST increased rapidly in both provinces over the last 25 years (Fig. 7c). Air temperature also increased in NS between both periods (Fig. 8a), again with a greater increase in

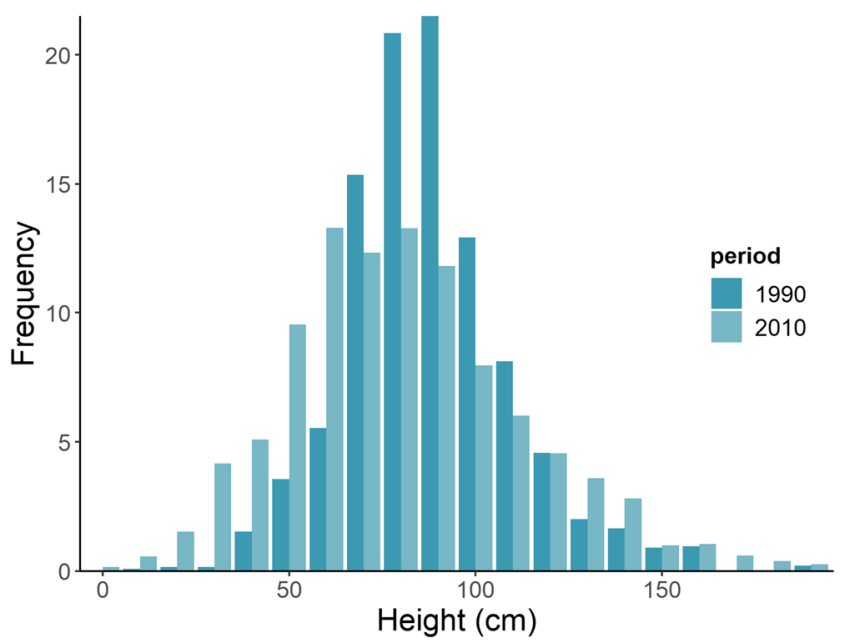

Fig. 4 Frequency distribution of Ascophyllum nodosum clump height in the 1990s and 2010s in Nova Scotia, Canada late summer and early fall than in the spring (Fig. 8b, c). Conversely, air temperature remained constant in NB between periods. Furthermore, the average annual number of days with recorded temperature above $26{ }^{\circ} \mathrm{C}$ more than doubled be-

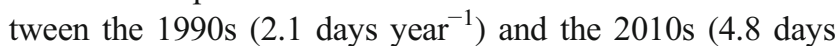
year $^{-1}$ ) in NS while it remained constant in NB (3 days year ${ }^{-1}$ in the 1990s and 3.4 days $\mathrm{year}^{-1}$ in the 2010s).

\section{Discussion}

While it is relatively simple to measure the short-term impact of biomass removal through experimental manipulation, field experiments rarely last for decades, except for rare exceptions (Ingólfsson and Hawkins 2008; Gendron et al. 2018). This study represents the first attempt at comparing the biomass and height of A. nodosum over a 20-year period of continual commercial harvest and provides insights into the potential long-term impact of the harvesting of A. nodosum as it is managed in eastern Canada.

\section{Harvest impact-height}

Compared to some kelp species that can grow several centimeters a day (Stewart et al. 2009), A. nodosum is a slowgrowing species. Annual shoot elongation for A. nodosum varies between sites depending on environmental conditions but generally ranges between 10 and $20 \mathrm{~cm}$ per year in eastern Canada (see Kay et al. 2016a for review). Therefore, a 100-cm clump could theoretically take several years to regain its original height if cut at the minimum allowed cutting height of $12.7 \mathrm{~cm}$. Under an annual harvesting rate of $17-25 \%$ of the standing stock biomass, we may expect that the same clump would be cut again within 4-6 years, not allowing enough time for it to recover fully. Although some short-term studies have shown a relatively rapid recovery of the biomass and height of A. nodosum after harvest (Ugarte et al. 2006; Phillippi et al. 2014), others with more intense harvesting treatments have suggested that several years would be needed for recovery (e.g., Ingólfsson and Hawkins 2008). These observations combined with the slow growth rates have led some to postulate that, over time, the harvest would have a negative impact on the height of $A$. nodosum clumps and that clumps would inevitably become shorter and bushier (Seeley and Schlesinger 2012). Our results indicate that this is largely not the case for height. In NB, where only modest amounts of $A$. nodosum had been harvested prior to our initial measurements, we observed an overall increase in the average clump height of $13.8 \mathrm{~cm}$ and no change in the biomass after 20 years. Whether the harvest played a role in this increase is difficult to assess. Clump heights within the unharvested sectors are similar to the harvested sectors. If harvesting activities had a lasting negative impact on the height of the A. nodosum canopy, 
Fig. 5 Bars represent the average biomass $\left(\mathbf{a}, \mathrm{kg} \mathrm{m}^{-2}\right)$ and height (b, cm) of Ascophyllum nodosum within each region in New Brunswick and for each period (1990s and 2010s)

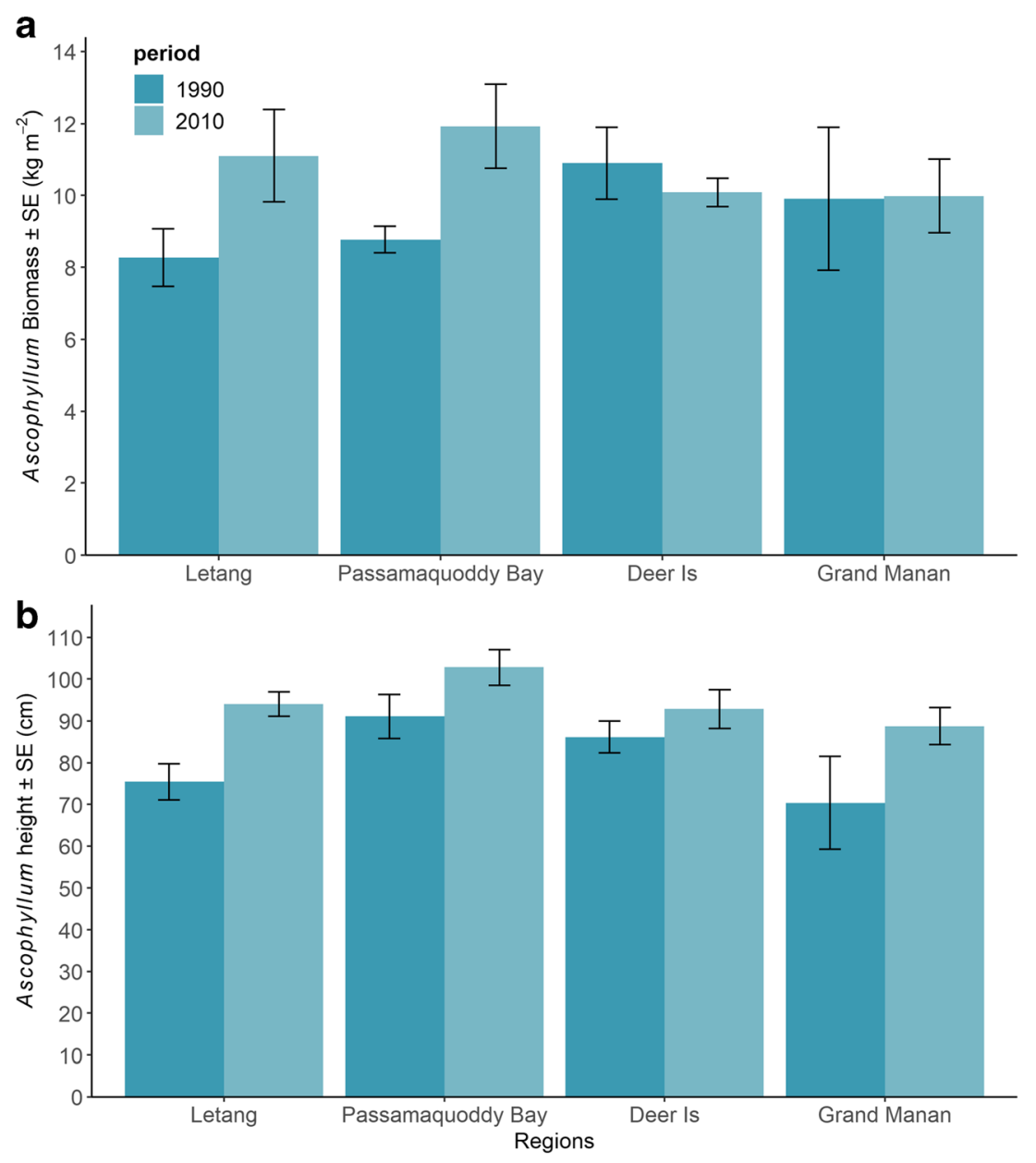

we would expect average height in unharvested sectors to be much higher than in harvested sectors.

In NS, we observed a $7.7-\mathrm{cm}$ reduction in clump height over a 20 -year period. This is less than the 10.6 -cm average yearly tip elongation measured in Lobster Bay over the last 4

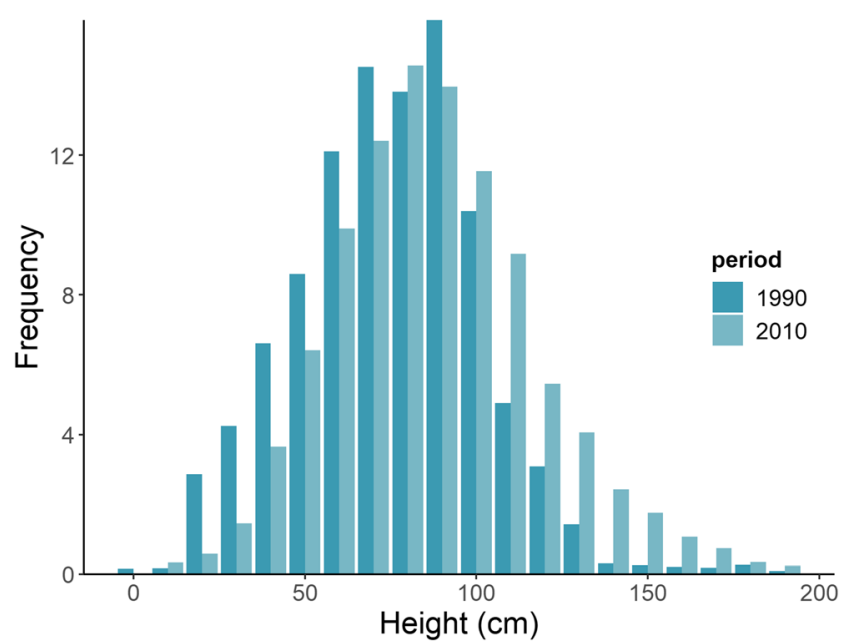

Fig. 6 Frequency distribution of Ascophyllum nodosum clump height in the 1990s and 2010s in New Brunswick, Canada years (ASL, unpublished data). Since sampling was done concomitantly with the harvest in both provinces, and that at the time of sampling up to $25 \%$ of the biomass had been removed from sampling sites in NS, height should theoretically be back to its 1990 s level after a single year without harvesting.

The discrepancy between the relatively slow rate of elongation of A. nodosum and the lack of negative impact of the harvest on height is likely due to the harvesting method that is being used in these provinces and how it differs from smallscale experiments that have informed prior predictions. While most small-scale experiments have focused on small plots where all clumps were uniformly cut to achieve a specific cutting height (Phillippi et al. 2014; Gendron et al. 2018) or the removal of a proportion of the biomass (Hamilton and Nudds 2003), the real world harvest of A. nodosum is much patchier and less intensive. In Canada, the tool used, a cutter rake (described by Ugarte et al. 2006), only allows the harvester to cut a certain proportion of each clump. The teeth of the cutting rake which retain the cut shoots quickly fill up, preventing more shoots from being cut. This results in a thinning of the shoots, with many tall shoots left uncut, rather than complete removal of the canopy. Once a clump has been thinned, it becomes less attractive to the harvester who will 

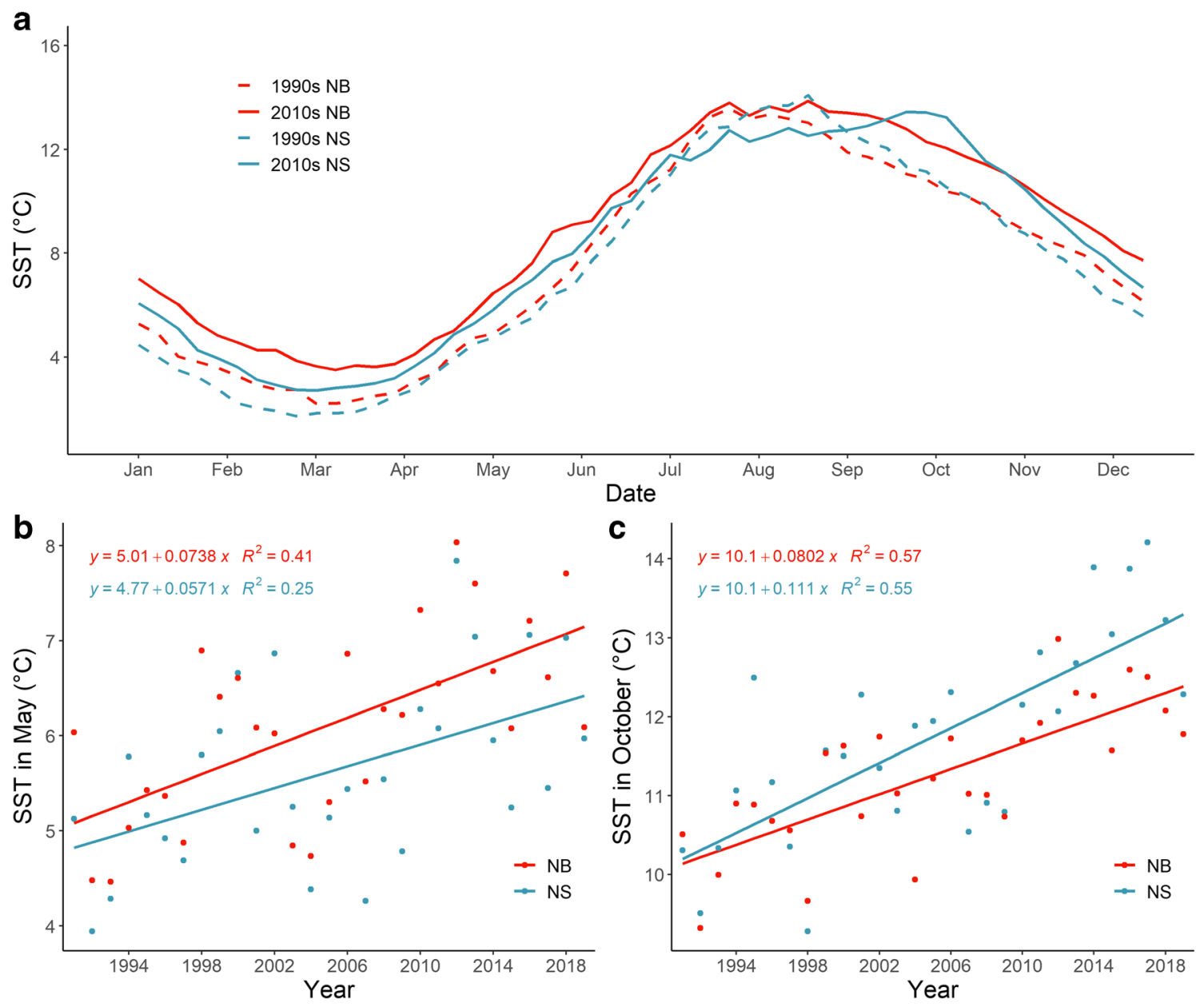

Fig. 7 Weekly average of satellite-derived sea-surface temperature (SST) for New Brunswick and Nova Scotia during the 1990s and 2010s (a). Trend in monthly average SST in May (b) and October (c) for New Brunswick and Nova Scotia between 1991 and 2019. Data were obtained

from the NOAA 0.25-degree Daily Optimum Interpolation Sea Surface Temperature, V2.1, and represent the averaged temperature over the extent of the study areas in Nova Scotia and New Brunswick

move along the bed in search of denser clumps (R Ugarte, pers. obs.). Harvesters use small skiffs (ca. $4 \mathrm{~m}$ in length; Fig. 1a) that drift along with the tides, currents, and wind, often preventing harvesters from spending an extended period at the same location. This results in a mosaic of patches with various degrees of harvest intensity within a bed. In that regard, the method employed by the individual harvester will likely play a more significant role than the tool being used. Both hand harvesting at low tide and mechanical harvesting can produce patchy and uniform harvesting intensity. In the case of a mechanical harvester, the bathymetry will greatly affect whether a uniform harvest is even possible.

Moderate harvesting can also have a positive impact on A. nodosum because canopy removal enhances the growth of short shoots in A. nodosum stands by increasing light availability (Cousens 1985; Lazo and Chapman 1996). Following an experimental commercial harvest in NB, suppressed shoots $(20-60 \mathrm{~cm})$ in highly harvested plots $(>50 \%$ biomass removal) grew up to 2.5 times faster than those in unharvested plots
(Ugarte et al. 2006). This increased growth of the understory promotes recruitment of shoots to the canopy. While individual shoots cut near the minimum cut height of $12.7 \mathrm{~cm}$ would take several years to regain their pre-harvest height, several unharvested shoots are left untouched, and shorter shoots fill in the gaps. So, while the impact on the individual shoots may be lasting, the impact on the clump or the bed is rapidly compensated by accelerated growth of new shoots. Unless the majority of shoots are cut, there is no significant reduction in canopy height (Hamilton 2001). Furthermore, the harvest is similar to the natural breaking of tall shoots during storms (Ugarte 2010). In most locations, other than the most protected bays, shoots and clumps will eventually break upon reaching a certain height. Drag will become too great and either the holdfast (or part of it, Ugarte 2010) will be removed, or shoots will break. While holdfasts could theoretically be several decades old, unbroken individual shoots are rarely older than 12-16 years old based on the number of vesicles along the main axis (J-S Lauzon-Guay, pers. obs.). Combined, 


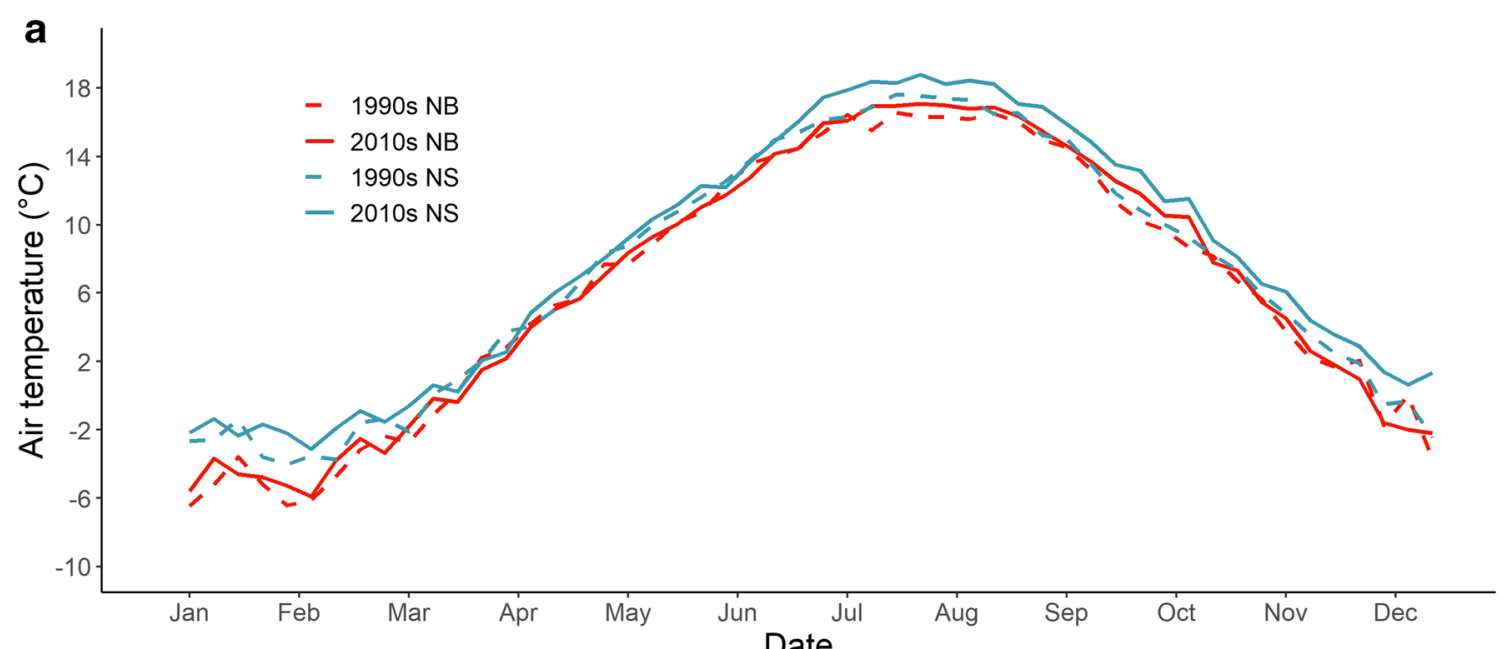

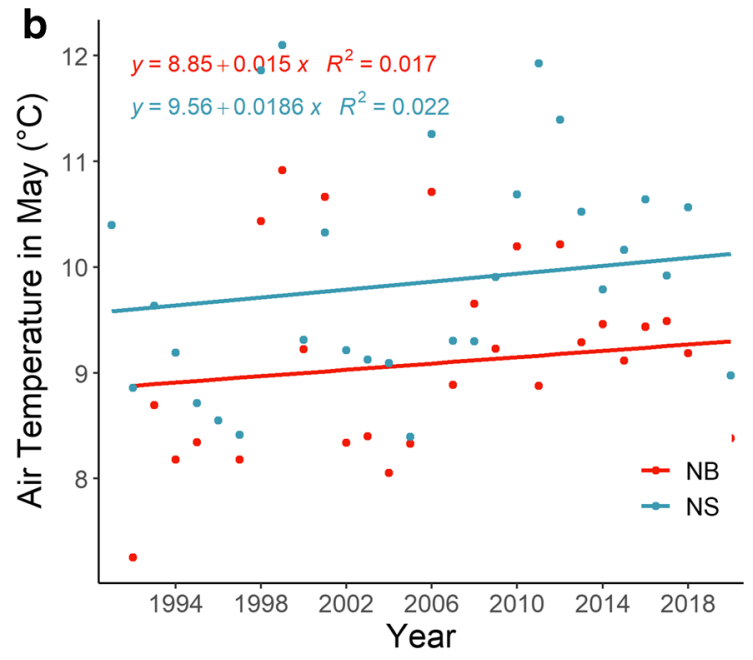

Fig. 8 Weekly average of air temperature for New Brunswick and Nova Scotia during the 1990s and 2010s (a). Trend in monthly average air temperature in May (b) and October (c) for New Brunswick and Nova

the patchy harvest, the increased growth of suppressed shoots, and the maximum height imposed by wave action explain why despite over 20 years of continuous harvesting, we have seen no meaningful long-term cumulative impact of the harvest on the height of $A$. nodosum in either province. Any decrease observed is smaller than that of the annual growth.

\section{Harvest impact—biomass}

Despite its relatively slow elongation rates, $A$. nodosum is a productive alga, generally producing $40 \%$ (and up to $70 \%$ ) of its biomass annually (Cousens 1985; Vadas et al. 2004). Gendron et al. (2018) conducted a 28-year harvesting experiment where they cut all $A$. nodosum shoots either 15 or $30 \mathrm{~cm}$ from the holdfast at a frequency of 1 to 5 years, mimicking a walk-on harvest rather than the boat and rake method used in our study. Although a longer interval between harvests had a positive effect, all treatment combinations resulted in a reduction of harvested biomass over time. The uniformity of the

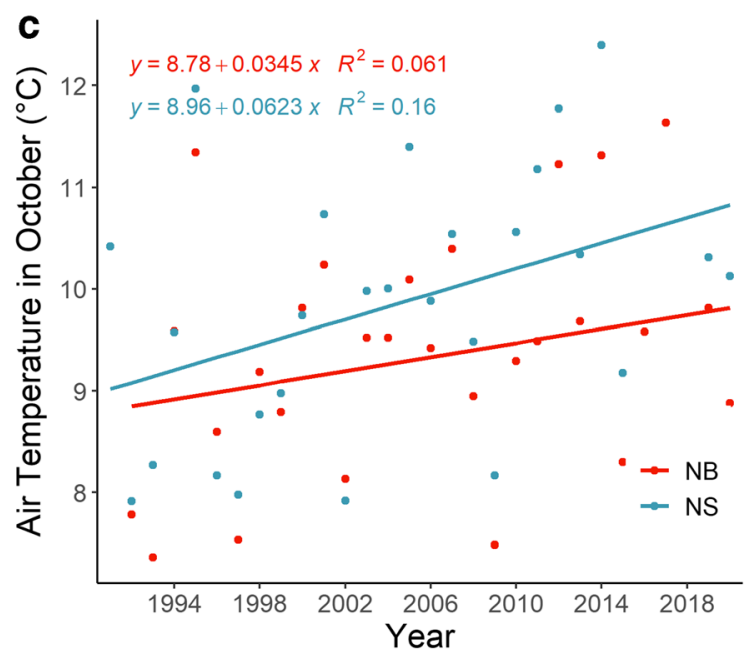

Scotia between 1991 and 2019. Data were collected by Environment and Natural Resources Canada from the Point Lepreau weather station in New Brunswick and Yarmouth Airport in Nova Scotia

walk-on harvest along with the high proportion of the biomass removed, $100 \%$ of the biomass above the cutting height compared to $17-25 \%$ in this study, explain the reduction in biomass observed over time. Conversely, when a smaller proportion of the biomass is harvested, recovery can occur within 1 year after harvest (Ugarte et al. 2006; Trott and Larsen 2012). The current regulations in NB and NS restrict the harvest to 17 and $25 \%$ of the biomass, respectively, which translates into the removal of 40 to $60 \%$ of the annual production. This restriction leaves a margin of untouched production $(40$ $60 \%$ ) that can act as a buffer in case of natural loss due to storm or ice damage. Seeley and Schlesinger (2012) have suggested that the current harvesting intensity is excessive because it represents a greater proportion of the net primary production than that of the consumption by herbivores in grasslands and macroalgal communities. This is not supported by our results where both biomass and height are maintained over time under a $17-25 \%$ harvest rate. Other factors may control herbivory in different systems and herbivory levels 
may not necessarily relate directly to plant productivity, nor should they represent a maximum harvesting rate.

Under complete removal, A. nodosum is generally initially replaced by Fucus vesiculosus (Keser et al. 1981; Jenkins et al. 1999; Bertness et al. 2002; Cervin et al. 2004; Ingólfsson and Hawkins 2008) and may take several years (4 to 15) to fully recover (Keser et al. 1981; Ingólfsson and Hawkins 2008). The current harvesting regulations allow only a certain proportion of the biomass to be removed (17 and $25 \%$ for NB and NS respectively) and limit the removal of holdfasts. Ascophyllum nodosum remains the dominant algal species despite the harvest, with $F$. vesiculosus accounting for less than $6 \%$ of the algal biomass in harvested A. nodosum beds. Its abundance has fluctuated around this level over the last 15 years of field sampling and as a proportion of harvested material in NS and NB (2003-2008: Ugarte et al. 2009, 20092020: ASL unpublished data).

While our 1990s data for NB were collected at the onset of the harvest, Lobster Bay had already been harvested for several decades by that point (Ugarte and Sharp 2012). Sharp and Tremblay (1989) reviewed the biomass surveys conducted in NS and NB before the 1990s. Between 1978 and 1988, A. nodosum varied between 8.0 and $14.0 \mathrm{~kg} \mathrm{~m}^{-2}$ in Lobster Bay and between 4.0 and $14.0 \mathrm{~kg} \mathrm{~m}^{-2}$ along the South Shore. In NB, data from the 1980s suggest pre-harvest biomass of $8.7 \mathrm{~kg} \mathrm{~m}^{-2}$ on average. These values are similar to the ranges we observed in both provinces. The only data for Lobster Bay preceding large-scale commercial harvest are those of MacFarlane (1952) who found an average biomass of $19.2 \mathrm{~kg} \mathrm{~m}^{-2}$ for all rockweeds combined (A. nodosum and Fucus spp.). MacFarlane sampled a single quadrat at each site in "areas of heavy density" only, and it is, therefore, difficult to compare this estimate to ours. Over $10 \%$ of our quadrats and some of our transects had biomass greater than $19.2 \mathrm{~kg}$ $\mathrm{m}^{-2}$ in the 2010s. Based on our sampling over the years covering a broad geographical scale in Europe and North America, we have never encountered as high of an average a biomass as that reported by MacFarlane (1952) for any region.

We observed wide variations in both biomass and height of A. nodosum between sites and regions and broad overlap between provinces but with overall taller clumps and higher biomass in NB than NS. Kay et al. (2016b) found more biomass as well as taller and wider clumps of $A$. nodosum at two sites in Lobster Bay, NS, than at four sites near Deer Island, NB. While we observed similar or slightly smaller values in NS, we observed larger average heights and biomass in all regions in NB than those reported by Kay et al. (2016b), highlighting the fact that broad generalization at large spatial scale cannot be inferred from a small number of sites. Growing conditions can be influenced by local factors such as nutrient input from rivers and aquaculture sites (White et al. 2011) as well as water flow (Mathieson et al. 1977; Cousens 1982) and temperature (Strömgren 1977) that can vary locally and a few sites from each province cannot provide a representative estimate. While our sampling sites covered a broad geographical range, our results may not apply to all A. nodosum beds in eastern Canada especially those in regions with much lower growth rates.

\section{Community impact}

Lotze et al. (2019) have reviewed the canopy and community impact of A. nodosum harvesting based on short-term studies and found that the type of harvest played a major role in mitigating the impacts. While a broad range of species has been found in A. nodosum beds (Seeley and Schlesinger 2012), little is known about the specific requirements of these species as to the $A$. nodosum beds. For example, while intertidal and subtidal structurally complex habitats (e.g., eelgrass, rocky habitat with or without attached vegetation) were recently designated as essential habitat for juvenile Atlantic cod (Gadus morhua) (New England Fishery Management Council 2017), the level of vegetation required (if any) has not been assessed. Another economically important species, the American lobster (Homarus americanus), is generally absent from $A$. nodosum beds except for a few individuals $\left(0.0065\right.$ individuals $\left.\mathrm{m}^{-2}\right)$ along the lower margin during high tide (Schmidt et al. 2011). There is no available information on the role played by $A$. nodosum bed on lobster abundance. Despite that fact, A. nodosum beds are mentioned as important habitat for lobsters (Seeley and Schlesinger 2012, Jeffery et al. 2020) using references that do not mention $A$. nodosum beds (e.g., Karnofsky et al. 1989; Cowan 1999). However, considering the lack of large changes in the biomass or height of A. nodosum that we have observed, it is unlikely that the harvest would significantly impact the habitat value of A. nodosum beds for lobsters or most other species.

Furthermore, during a 3-year study in NB, Van Guelpen and Pohle (2014) found no link between the harvest of A. nodosum and any changes in the ichthyoplankton community. Studies looking at the potential impact of the harvest on associated fauna have generally found no short-term effect (Fegley 2001; Hamilton and Nudds 2003; Trott and Larsen 2012; Phillippi et al. 2014). While the removal of A. nodosum canopy has been shown to affect birds in some cases, that effect only occurs when most of the canopy is removed (Hamilton and Nudds 2003).

The harvest of $A$. nodosum likely results in a net decrease in the production of detrital matter (Halat et al. 2015). Upon reaching its maximum biomass, with a 40 to $70 \%$ annual production, equivalent biomass is either consumed or lost during storms each year. We can then expect the harvest to reduce the contribution of A. nodosum to the detrital pool. Kelp detritus is an essential subsidy to the subtidal environment (Krumhansl and Scheibling 2012), but data are lacking as to the contribution of A. nodosum to subtidal habitats. Contrary to local kelp species, 
A. nodosum floats and is often cast on shores following storms, where it decomposes and provides feeding grounds for birds. While some of it can be found in the detrital pool of estuaries (Mayer et al. 1988), how much of it would be carried to subtidal habitat or even to deeper water where it might become sequestered is unknown. So far, A. nodosum nor any other Fucales have not been identified among deep-sea detritus (Ortega et al. 2019), but further work should be carried out to quantify it.

\section{Long-term environmental trends}

Several environmental factors have changed over the last 20 years that may have affected $A$. nodosum. Sea surface temperature has increased by an average of $0.03{ }^{\circ} \mathrm{C}$ per year over the last four decades in the Gulf of Maine making it one of the fastest-warming ocean water mass worldwide (Pershing et al. 2015). Coastal SST has changed over time in both provinces, with a warmer spring in NB and a warmer fall in NS. Ascophyllum nodosum grows more rapidly at warmer temperature until the high 10 s or low 20 s and stops at $23-25^{\circ} \mathrm{C}$ in the region (Keser et al. 2005; Wilson et al. 2015; Kay et al. 2016a). There are regional differences and Stengel and Dring (1997) have observed a decline in growth above $15-16^{\circ} \mathrm{C}$ in Ireland. The most rapid increases in growth occur at temperatures between 10 and $17.5^{\circ} \mathrm{C}$, where small increases in temperature cause large increases in growth (Strömgren 1983). Ascophyllum nodosum can have its fastest growth during low tide while exposed to air for a short period of time (Strömgren 1983). In recent years, we have observed A. nodosum with sun damage (brown and reddish coloration of the upper canopy as previously described by Brinkhuis et al. 1976; Fig. 1b) at several sites mostly in NS during prolonged hot and sunny conditions. This is consistent with the observed increase in the annual number of days with air temperature above the thermal threshold for the species in NS. Temperature deep inside bays can be several degrees warmer than the satellite-derived SST. This is especially true for Lobster Bay where water temperature has reached the mid-twenties in recent years and can remain above $20{ }^{\circ} \mathrm{C}$ for over 2 months in late summer (Dempsey et al. 2020), creating less optimal growing conditions for A. nodosum. Extensive surveys conducted over the last 30 years have not recorded water temperature above $19{ }^{\circ} \mathrm{C}$ in NB (Department of Fisheries and Oceans 2020). This suggests that the increased SST observed may have had a positive impact on the growth of $A$. nodosum in $\mathrm{NB}$, while any positive effect of increased water temperature in the Spring in NS may have been negated by the overly warm air and sea surface temperature in late summer/early fall. Furthermore, air temperature and $\mathrm{CO}_{2}$ concentration have an interactive positive effect on $\mathrm{CO}_{2}$ uptake in $A$. nodosum with $\mathrm{CO}_{2}$ concentration having the greatest effect in late winter-early spring (Longphuirt et al. 2013). If this increase in $\mathrm{CO}_{2}$ uptake results in increased growth, this could partly explain the overall increase in height and biomass observed in NB where spring
SST have increased more markedly. Increasing shoot elongation with temperature has already been observed for $A$. nodosum at its northern distribution (Marbà et al. 2017). There are several other environmental factors that should be investigated further (e.g., grazing and competitive pressure, sea level, ice cover). Fish farms can also have a positive impact on the growth of seaweeds (White et al. 2011; Fossberg et al. 2018) and salmon production in open nets has doubled in NB over the last 20 years with most farms in close proximity to our sampling sites (Government of New Bruwnsick 2020) while there are very few fish farms in NS (Government of Nova Scotia 2020). These environmental factors combined with the lower harvesting rate in NB compared to NS (17 vs 25\%) are likely contributing to the small decrease in height in NS and the increase in NB over the last 20 years. They highlight the fact that a unique harvesting rate may not be appropriate for all sites and that local and regional growing conditions should be considered. Furthermore, control sites with baseline data should be implemented in all harvested regions to ensure that proper comparisons can be made as the environmental conditions change.

The management of the A. nodosum harvest in eastern Canada over the last two decades has been successful in maintaining the general integrity of the biomass and height of the resource and to match wording found at the end of abstract is sustainable. How a changing climate and the foreseeable increased mechanization of the industry to cope with an aging workforce combined with increasing demand for seaweed will affect that sustainability will have to be closely monitored. Management will have to adapt to these changing conditions especially as the harvest expands to new areas with marginal resource availability. Continuous adaptation of best harvesting practices that were developed in NS and NB over the last 20 years is needed considering the potential impact of climate change and adoption of new technologies.

Supplementary Information The online version contains supplementary material available at https://doi.org/10.1007/s10811-021-02427-x.

Acknowledgements In memory of Kenny Murphy (1957-2021), Nova Scotia Resource Manager and Acadian Seaplants employee for 27 years. His dedication to harvesters and the management of seaweed has been an integral part of the success of Acadian Seaplants. We thank all those who have taken part in the field sampling over the years for their contribution to this work and our colleagues at ASL for their support. Michéal MacMonagail, Alison Feibel, and two anonymous reviewers provided valuable comments on earlier drafts of this manuscript. We would also like to acknowledge Acadian Seaplants and more specifically its founder, Louis E. Deveau, for believing in the importance of a sustainable harvest and for investing in Science from the very beginning.

\section{References}

Åberg P (1989) Distinguising between genetic individuals in Ascophyllum nodosum populations on the Swedish west coast. Br Phycol J 24:183-190 
Anonymous (1907) Cold lunches and wet to the skin. Sunday Herald, Boston, MA

Anonymous (1994) Memorandum of understanding between the New Brunswick. Department of Fisheries and Aquaculture and the Department of Fisheries and Oceans, Canada 3 pp

Bertness MD, Trussell G, Ewanchuk P, Silliman BR (2002) Do alternate stable community states exist in the Gulf of Maine rocky intertidal zone? Ecology 83:3434-3448

Brinkhuis BH, Jones RF, Brook S (1976) The ecology of temperate saltmarsh Fucoids. II. Mar Biol 348:339-348

Cervin G, Lindegarth M, Viejo RM, Åberg P (2004) Effects of smallscale disturbances of canopy and grazing on intertidal assemblages on the Swedish west coast. J Exp Mar Bio Ecol 302:35-49

Cousens R (1982) The effect of exposure to wave action on the morphology and pigmentation of Ascophyllum nodosum (L.) Le Jolis in south-eastern Canada. Bot Mar 25:191-196

Cousens R (1985) Frond size distributions and the effects of the algal canopy on the behaviour of Ascophyllum nosodum (L.) Le Jolis. J Exp Mar Bio Ecol 92:231-249

Cowan DF (1999) Method for assessing relative abundance, size distribution, and growth or recently settled and early juvenile lobsters (Homarus americanus) in the lower intertidal zone. J Crustac Biol 19:738-751

Dempsey D, Torrie N, Lewis-McCrea L, Horricks R, Reid G (2020) Acadian seaplants - updated CMAR oceanographic data report for Lobster Bay. Center for Marine Applied Research, Dartmouth, NS

Department of Fisheries and Oceans (2020) Passamaquoddy Bay monthly conductivity temperature and density (CTD) sampling (1989present). Available from https://open.canada.ca/data/en/dataset/ 12184962-7879-4214-aef0-b31162f04a27, [accessed 1 September 2020]

Evans FD, Critchley AT (2014) Seaweeds for animal production use. J Appl Phycol 26:891-899

FAO (2018) Fishery statistical collections. Food and Agriculture Organization of the United Nations, Rome, Italy. http://www.fao. org/fishery/statistics/. Accessed September 2020

Fegley J (2001) Ecological implications of rockweed, Ascophyllum nodosum (L.) Le Jolis, harvesting. Dissertation, University of Maine.

Fossberg J, Forbord S, Broch OJ, Malzahn AM, Jansen H, Handå A, Førde H, Bergvik M, Fleddum AL, Skjermo J, Olsen Y (2018) The potential for upscaling kelp (Saccharina latissima) cultivation in salmon-driven integrated multi-trophic aquaculture (IMTA). Front Mar Sci 9:1-12

Gendron L, Merzouk A, Bergeron P, Johnson LE (2018) Managing disturbance: the response of a dominant intertidal seaweed Ascophyllum nodosum (L.) Le Jolis to different frequencies and intensities of harvesting. J Appl Phycol 30:1877-1892

Government of New Bruwnsick (2020) Marine Aquaculture Site Mapping Program (MASMP). https://nbdnr.maps.arcgis.com/apps/ w e b a p p vi e w e r / i n d e x . h t m l ? i d = $24 \mathrm{c} 65 \mathrm{e} 8718724 \mathrm{c} 5 \mathrm{db} 1 \mathrm{de} 77899172630 \mathrm{~d} \&$ locale=en (accessed 1 September 2020)

Government of Nova Scotia (2020) Nova Scotia Fisheries and Aquaculture Site Mapping Tool. https://novascotia.ca/fish/ aquaculture/site-mapping-tool/ (accessed 1 September 2020)

Guiry MD, Morrison L (2013) The sustainable harvesting of Ascophyllum nodosum (Fucaceae, Phaeophyceae) in Ireland, with notes on the collection and use of some other brown algae. J Appl Phycol 25:1823-1830

Halat L, Galway ME, Gitto S, Garbary DJ (2015) Epidermal shedding in Ascophyllum nodosum (Phaeophyceae): Seasonality, productivity and relationship to harvesting. Phycologia 54:599-608

Hamilton DJ (2001) Feeding behavior of common eider ducklings in relation to availability of rockweed habitat and duckling age. Waterbirds 24:233-241
Hamilton DJ, Nudds T (2003) Effects of predation by common eiders (Somateria mollissima) in an intertidal rockweed bed relative to an adjacent mussel bed. Mar Biol 142:1-12

Ingólfsson A, Hawkins SJ (2008) Slow recovery from disturbance: a 20 year study of Ascophyllum canopy clearances. J Mar Biol Assoc UK 88:689-691

Jeffery NW, Heaslip SG, Stevens LA, Stanley RRE (2020) Biophysical and ecological overview of the Eastern Shore Islands Area of Interest ( AOI ). DFO Can Sci Advis Sec Res Doc 2019/025. xiii $+138 p$

Jenkins SR, Norton TA, Hawkins SJ (1999) Interactions between canopy forming algae in the eulittoral zone of sheltered rocky shores on the Isle of Man. J Mar Biol Assoc UK 79:341-349

Karnofsky EB, Atema J, Elgin RH (1989) Field observations of social behavior, shelter use, and foraging in the lobster, Homarus americanus. Biol Bull 176:239-246

Kay LM, Schmidt AL, Wilson KL, Lotze HK (2016a) Interactive effects of increasing temperature and nutrient loading on the habitatforming rockweed Ascophyllum nodosum. Aquat Bot 133:70-78

Kay LM, Tyler DE, Schmidt AL, Lotze HK (2016b) Regional differences and linkage between canopy strusture and community composition of rockweed habitats in Atlantic Canada. Mar Biol 163:251

Keser M, Vadas RL, Larson BR (1981) Regrowth of Ascophyllum nodosum and Fucus vesiculosus under various harvesting regimes in Maine, U.S.A. Bot Mar 24:29-38

Keser M, Swenarton JT, Foertch JF (2005) Effects of thermal input and climate change on growth of Ascophyllum nodosum (Fucales, Phaeophyceae) in eastern Long Island Sound (USA). J Sea Res 54:211-220

Krumhansl KA, Scheibling RE (2012) Production and fate of kelp detritus. Mar Ecol Prog Ser 467:281-302

Lazo ML, Chapman ARO (1996) Effects of harvesting on Ascophyllum nodosum (L.) Le Jol (Fucales, Phaeophyta): a demographic approach. J Appl Phycol 8:87-103

Lazo ML, Chapman ARO (1998) Components of crowding in a modular seaweed: sorting through the contradictions. Mar Ecol Prog Ser 174: 257-267

Longphuirt SN, Eschmann C, Russell C, Stengel DB (2013) Seasonal and species-specific response of five brown macroalgae to high atmospheric $\mathrm{CO}_{2}$. Mar Ecol Prog Ser 493:91-102

Lorentsen SH, Sjøtun K, Grémillet D (2010) Multi-trophic consequences of kelp harvest. Biol Conserv 143:2054-2062

Lotze HK, Milewski I, Fast J, Kay L, Worm B (2019) Ecosystem-based management of seaweed harvesting. Bot Mar 62:395-409

Mac Monagail M, Cornish L, Morrison L, Araújo R, Critchley AT (2017) Sustainable harvesting of wild seaweed resources. Eur J Phycol 52: 371-390

MacFarlane C (1952) A survey of certain seaweeds of commercial importance in southwest Nova Scotia. Can J Bot 30:78-97

Marbà N, Krause-Jensen D, Olesen B, Christensen PB, Merzouk A, Rodrigues J, Wegeberg S, Wilce RT (2017) Climate change stimulates the growth of the intertidal macroalgae Ascophyllum nodosum near the northern distribution limit. Ambio 46:119-131

Mathieson AC, Tveter E, Daly M, Howard J (1977) Marine algal ecology in a New Hampshire tidal rapid. Bot Mar 20:277-290

Mayer LM, Macko SA, Cammen L (1988) Provenance, concentrations and nature of sedimentary organic nitrogen in the gulf of Maine. Mar Chem 25:291-304

New England Fishery Management Council (2017) Omnibus essential habitat amendment 2: EHF and HAPC designation alternatives and environmental impacts. Newburyport, MA, USA

Ortega A, Geraldi NR, Alam I, Kamau AA, Acinas SG, Logares R, Gasol JM, Massana R, Krause-Jensen D, Duarte CM (2019) Important contribution of macroalgae to oceanic carbon sequestration. Nat Geosci 12:748-754 
Pershing AJ, Alexander MA, Hernandez CM, Kerr LA, Le Bris A, Mills KE, Nye JA, Record NR, Scannell HA, Scott JD, Sherwood GD, Thomas AC (2015) Slow adaptation in the face of rapid warming leads to collapse of the Gulf of Maine cod fishery. Science 350:809812

Phillippi A, Tran K, Perna A (2014) Does intertidal canopy removal of Ascophyllum nodosum alter the community structure beneath? J Exp Mar Bio Ecol 461:53-60

R Core Team (2020) R: a language and environment for statistical computing. R Foundation for Statistical Computing, Vienna, Austria http://www.r-project.org/

Rebours C, Marinho-Soriano E, Zertuche-González JA, Hayashi L, Vásquez JA, Kradolfer P, Soriano G, Ugarte R, Abreu MH, BayLarsen I, Hovelsrud G, Rødven R, Robledo D (2014) Seaweeds: an opportunity for wealth and sustainable livelihood for coastal communities. J Appl Phycol 26:1939-1951

Schmidt AL, Coll M, Romanuk TN, Lotze HK (2011) Ecosystem structure and services in eelgrass Zostera marina and rockweed Ascophyllum nodosum habitats. Mar Ecol Prog Ser 437:51-68

Seeley RH, Schlesinger WH (2012) Sustainable seaweed cutting? The rockweed (Ascophyllum nodosum) industry of Maine and the Maritime Provinces. Ann N Y Acad Sci 1249:84-103

Selvin S (1996) Stastitical analysis of epidemiologica data. Oxford University Press, New York 488 pp

Sharp GJ, Tremblay DM (1989) An assessment of Ascophyllum nodosum resources in Scotia Fundy. DFO Can Atl Fish Sci Adv Comm Res Doc 89/1. $19 \mathrm{p}$

Shukla PS, Mantin EG, Adil M, Bajpai S, Critchley AT, Prithiviraj B (2019) Ascophyllum nodosum -based biostimulants : sustainable applications in agriculture for the stimulation of plant growth, stress tolerance, and disease management. Front Plant Sci 10:1-22

Stengel D, Dring M (1997) Morphology and in situ growth rates of plants of Ascophyllum nodosum (Phaeophyta) from different shore levels and responses of plants to vertical transplantation. Eur J Phycol 32: 193-202

Stewart HL, Fram JP, Reed DC, Williams SL, Brzezinski MA, Maclntyreb S, Gaylord B (2009) Differences in growth, morphology and tissue carbon and nitrogen of Macrocystis pyrifera within and at the outer edge of a giant kelp forest in California, USA. Mar Ecol Prog Ser 375:101-112

Strömgren T (1977) Short-term effects of temperature upon the growth of intertidal Fucales. J Exp Mar Bio Ecol 29:181-195

Strömgren T (1983) Temperature-length growth strategies in the littoral alga Ascophyllum nodosum (L.). Limnol Oceanogr 28:516-521
Trott TJ, Larsen PF (2012) Evaluation of short-term changes in rockweed (Ascophyllum nodosum) and associated epifaunal communities following cutter rake harvesting in Maine. Report to the Department of Marine Resources. W. Boothbay Harbor, Maine 31 pp

Ugarte RA (2010) An evaluation of the mortality of the brown seaweed Ascophyllum nodosum (L.) Le Jol. produced by cutter rake harvests in southern New Brunswick, Canada. J Appl Phycol 23:401-407

Ugarte RA, Sharp G (2001) A new approach to seaweed management in Eastern Canada: the case of Ascophyllum nodosum. Cah Biol Mar 42:63-70

Ugarte RA, Sharp GJ (2012) Management and production of the brown algae Ascophyllum nodosum in the Canadian maritimes. J Appl Phycol 24:409-416

Ugarte RA, Sharp GJ, Moore B (2006) Changes in the brown seaweed Ascophyllum nodosum (L.) Le Jol. plant morphology and biomass produced by cutter rake harvests in southern New Brunswick, Canada. J Appl Phycol 18:351-359

Ugarte RA, Critchley A, Serdynska AR, Deveau JP (2009) Changes in composition of rockweed (Ascophyllum nodosum) beds due to possible recent increase in sea temperature in Eastern Canada. J Appl Phycol 21:591-598

Vadas RL, Wright WA, Beal BF (2004) Biomass and productivity of intertidal rockweeds (Ascophyllum nodosum Lejolis) in Cobscook Bay. Northeast Nat 11:123-142

Van Guelpen L, Pohle G (2014) Short- and long-term impact of rockweed harvesting on the intertidal fish community in southwest New Brunswick. Huntsman Marine Science Center. Final Report to the New Brunswick Wildlife Trust Fund. Project F303-052. 29p

Vásquez JA (2008) Production, use and fate of Chilean brown seaweeds: re-sources for a sustainable fishery. J Appl Phycol 20:457-467

White K, Kim J, Garbary D (2011) Effects of land-based fish farm effluent on the morphology and growth of Ascophyllum nodosum (Fucales, Phaeophyceae) in southwestern Nova Scotia. Algae 26: 253-263

Wilson KL, Kay LM, Schmidt AL, Lotze HK (2015) Effects of increasing water temperatures on survival and growth of ecologically and economically important seaweeds in Atlantic Canada: implications for climate change. Mar Biol 162:2431-2444

Publisher's note Springer Nature remains neutral with regard to jurisdictional claims in published maps and institutional affiliations. 